New thoracican cirripedes (Crustacea) from the Portland and Purbeck Groups (Tithonian-Berriasian) of Dorset, United Kingdom

Andy Gale

aSchool of Earth and Environmental Sciences, University of Portsmouth, Burnaby Building, Burnaby Road, Portsmouth PO1 3QL, United Kingdom

E-mail: andy.gale@port.ac.uk

Abstract. The first cirripedes from the Portland and Purbeck groups of southern England are described, and referred to two new species, Loriolepas whytei sp. nov and Etcheslepas portlandensis sp. nov. They constitute the first records of cirripedes from the upper Tithonian (uppermost Jurassic) and Berriasian (lowermost Cretaceous) of western Europe. A new family, the Archaeolepadidae, is introduced for the extinct genera Archaeolepas and Loriolepas.

Key words. Jurassic, Cretaceous, stalked barnacles, southern England

\title{
Introduction
}

In 1928, Thomas Withers described the meagre cirripede material from the British Upper Jurassic, consisting of a small number of mostly broken valves washed from the Kimmeridge Clay of Buckinghamshire. In the Lower Cretaceous, the marine pre-Aptian strata had yielded only a single species from the Speeton Clay (Hauterivian) of Speeton, Yorkshire. Recent discoveries by Steve Etches (Etches Collection, Kimmeridge) of magnificently preserved, and locally abundant, cirripedes from the Kimmeridge Clay in Dorset have considerably improved our understanding of the taxonomy, phylogeny and palaeoecology of Late Jurassic forms (Gale 2014, 2018), but they remained unknown from the overlying Portland Group. In 2015, during a field excursion for students of the University of Portsmouth to Freshwater, on the Isle of Portland (Fig. 1) I collected a number of cirripede valves from the Cherty Member of the Portland Stone Formation, and further specimens on a subsequent visit. At this time, Paul Ensom told me that he had 
found a single cirripede valve in the Cinder Bed at Warbarrow Tout, Purbeck, Dorset (Ensom 1985b). I visited that section in 2016 and collected an additional 15 specimens. Subsequently, the Portland and Purbeck specimens proved to belong to two new species; these are the only late Tithonian and Berriasian records of the group from western Europe. These new records, together with material from the Kimmeridgian of Germany (Gale et al. 2019) and the Hauterivian of northern Germany (Gale 2019) partly infill a stratigraphical gap in the fossil record of the group.

\section{Stratigraphy and localities}

Cliffs and an old quarry at Freshwater, Isle of Portland. Exposures along the side of the steep path which passes through the Cherty Member of the Portland Stone Formation have yielded common cirripedes at a level 7-8 metres above the base of the member (Fig. 2B). The age is late Tithonian, Kerberites kerberus ammonite Zone (Coe 1996).

Worbarrow Tout, Dorset. The west side of Worbarrow Tout provides good exposures of the Cinder Bed at the base of the Durlston Formation, a brackish intercalation which is full of the oyster Praeexogyra distorta (see Ensom1985). Here, the Cinder Bed attains a thickness of $1.85 \mathrm{~m}$ (Fig. 2C). Barnacle valves occur only in a single, 10-cm-level, $1 \mathrm{~m}$ above the base. The Cinder Bed is middle Berriasian in age, falling within magnetochron M17 (W. Wimbledon, pers. comm., 2018).

\section{Abbreviations.}

DCM, Dorset County Museum, Dorchester, UK.

MIJML Etches Collection, Kimmeridge, Dorset, UK.

NHMUK Natural History Museum, London, UK.

\section{Systematic palaeontology}

Family Archaeolepadidae, new family

Diagnosis.Calcareous pedunculate cirripedes in which the tall capitulum is made up of six robust plates, including two scuta, two terga, a carina and a rostrum. Lateral plates absent. 
Included genera. Archaeolepas von Zittel, 1885 and Loriolepas Gale, 2015.

Remarks.Archaeolepas was included in the family Eolepadidae Buckeridge, 1983, in the original description of the family, on account of the similar plating configuration to that of Eolepas Withers, 1928. However, it has lately been shown that Eolepas has phosphatic plates (Gale and Schweigert 2015) which means that Archaeolepas and Loriolepas require a new family.

Genus Loriolepas Gale, 2015

Type species. Pollicipes suprajurensis de Loriol, in de Loriol and Pellat, 1867), by original designation.

Referred species. Archaeolepas decora Harbort, 1905; Pollicipes planulatus Morris, 1845 and $L$. whytei sp. nov.

Diagnosis. Archaeolepadids which possess a capitulum which is less than half the height of the peduncle. Peduncular plates small, polygonal, set in about 20 columns. Carina twothirds the height of tergum, strongly incurved towards tergum. Tergum possesses a sharply demarcated, flat-topped apicobasal ridge which forms a basal margin.

Loriolepas whytei sp. nov.

Diagnosis.Loriolepas in which the tergum possesses a broad, flat-topped apicobasal ridge which is straight, and terminates proximally in a basal margin. Scutum broad and low, lacking apicobasal ridge.

Material. Fifteen valves from the Cinder Bed (middle Berriasian) of Worbarrow Bay, Dorset. NHMUK and Dorset County Museum.

Types. The tergum illustrated in Figure $3 \mathrm{~K}$ is the holotype (NHMUK IC 1332). The other three illustrated valves are paratypes and are from the same horizon and locality (Fig. 3H,I, NHMUK IC 1333, IC 1334; Fig. 3J, DCM G.7260). 
Derivation of name. In honour of the work on barnacles by the late Dr Martin Whyte (formerly of Sheffield University).

Description.Terga twice as tall as broad, five sided, occludent margin short and straight (Fig. 3J, K). Upper carinal margin slightly longer than lower, with an obtuse angle between carinal margins.Tergal margin concave, scutal-occludent surface weakly depressed.Occludent ridge for scutal contact absent. A triangular apicobasal ridge extends from the apex to the base of the valve, where it forms a short, straight basal margin. Scuta (Fig. $3 \mathrm{H}, \mathrm{I}$ ) are triangular, and the height approximately equals the breadth. The occludent margin is convex, the tergal margin straight. Although the contact between the basal and rostral margins is not exposed, the growth lines (Fig. 3I) suggest that it is gently curved.

Remarks. Loriolepas whytei sp. nov. is closest to L. suprajurensis (Fig. 3A, D, E), from which it differs in the straight, rather than curved, apicobasal ridge and the absence of a ridge for scutal articulation. The occludent margin is straight in L. whytei sp. nov., but concave in $L$. suprajurensis. The scutum of $L$. whytei sp. nov. is shorter and broader than that of $L$. suprajurensis, and lacks an apicobasal ridge.

Occurrence. Cinder Bed, Purbeck Group, of Worbarrow Bay, Dorset. Middle Berriasian.

Family ?Zeugmatolepadidae Newman, 1996

Genus Etcheslepas Gale, 2014

Diagnosis. Capitulum broad, with tall upper latus and rostrolatus, and numerous (50+) smaller, imbricating lateral plates. Rostrum strongly convex, with four discrete surfaces.

Etcheslepas portlandensis sp. nov.

Fig. 4A-D

Diagnosis. Etcheslepas characterised by relatively few, well-separated and evenly spaced raised ridges on the valves which run parallel to the margins.

Material.Eighteen valves in NHMUK Coll. from the Cherty Member (Portland Stone Formation) at Freshwater, Portland, Dorset; upper Tithonian, Kerberites kerberus ammonite Zone. 
Types. The tergum figured in Fig. $4 \mathrm{D}$ is the holotype (NHMUK IC 1336). The other illustrated valves are paratypes (Fig.4A, tergum, NHMUK IC 1337; Fig. 4B, scutum, IC 1338; Fig. 4C, carina, IC 1339).

Derivation of name. After the Isle of Portland, Dorset, which yielded the material described here.

Description. Terga (Fig. 4A, B, D) nearly symmetrically rhombic in outline, slightly taller than broad. Upper and lower carinal margins gently convex, of equal length. Apicobasal ridge weak, curved towards the carinal margin. Occludent margin slightly concave, and a ridge for scutal articulation is present adjacent to the occludent margin. A weakly depressed region adjacent to this ridge bears shallow grooves beneath the prominent ridges. Sculpture consists of widely separated fine ridges, parallel with valve margins, approximately 50 microns apart. The triangular scutum (Fig. 4B) is as broad as tall with an elongated basal margin and a sharp apicobasal ridge, which separates a well-demarcated tergal surface. The growth lines are slightly less regular than on the terga. The carina (Fig. 4C) is rounded in cross section and tapers strongly towards the apex. It bears widely separated, low ridges like those on the terga, which are shaped like the letter ' $V$ ' towards the basal margin. The ridges become more closely spaced basally, probably indicating decreased growth towards maximum size, as for the terga.

Remarks. Etcheslepas portlandensis sp. nov. differs from E. durotrigensis (Fig. 4E, I) in the proportionately lower, more symmetrically rhombic terga and the more acutely angled (about $100^{\circ}$ ) growth lines on the carina. The sculpture is also very different; in $E$. durotrigensis, the growth ridges are very fine, numerous and closely spaced, whereas those in E. portlandensis sp. nov.are fewer and more widely spaced.

\section{Conclusions}

The first thoracican cirripedes from the upper Tithonian Portland Limestone Formation and the middle Berriasian Durlston Formation of Dorset are described. They are identified as belonging the archaeolepadid genus Loriolepas (L. whytei sp. nov.) and the zeugmatolepadid Etcheslepas 
(E. portlandensis sp. nov.). A new family, Archaeolepadidae, is erected for accommodation of the extinct genera Archaeolepas and Loriolepas. This is only the second record of a cirripede from the Berriasian Stage, worldwide.

\section{Acknowledgements}

I wish to thank Dr Bill Wimbledon for his advice on the stratigraphy and Dr Paul Ensom for telling me about the Worbarrow Bay discovery. I would like to thank Dr John Jagt (Maastricht) for his helpful and thorough review.

\section{References}

Buckeridge, J.S., 1983. Fossil barnacles (Cirripedia: Thoracica) of New Zealand and Australia. New Zealand Geological Survey, Palaeontological Bulletin 50, 1-151, 13 pls.

Coe, A.L., 1996. Unconformities within the Portlandian Stage of the Wessex Basin and their sequence stratigraphical significance. In: Hesselbo, S.P., Parkinson, D.N. (eds). Sequence stratigraphy in British geology. Geological Society, London, Special Publications 103, 109-143.

Darwin, C.R., 1851. A monograph on the sub-class Cirripedia, with figures of all the species. The Lepadidae, or pedunculated cirripedes. The Ray Society, London, xii + 400 pp., 10 pls.

Ensom, P.C., 1985a. An annotated section of the Purbeck Limestone Formation at Worbarrow Tout, Dorset. Proceedings of the Dorset Natural History and Archaeological Society 106, 87-91.

Ensom, P.C. 1985b. A barnacle from the Cinder Member, Purbeck Limestone Formation, Worbarrow Tout, Dorset. Proceedings of the Dorset Natural History and Archaeological Society 106,167.

Gale, A.S., 2014. New thoracican cirripedes (Crustacea) from the Jurassic and Cretaceous of the UK. Proceedings of the Geologists' Association125, 406-418.

Gale, A.S., 2015. Origin and phylogeny of the thoracican cirripede family Stramentidae. Journal of Systematic Palaeontology, http://dx.doi.org/10.1080/14772019.2015.1091149 
Gale, A.S., 2018. Stalked barnacles (Cirripedia, Thoracica) from the Upper Jurassic (Tithonian) Kimmeridge Clay of Dorset, UK; palaeoecology and bearing on the evolution of living forms. Proceedings of the Geologists' Association.

Gale, A.S., 2019, in press. Thoracican cirripedes (Crustacea) from the Hauterivian (Lower Cretaceous) of the Hannover district, Germany. Proceedings of the Geologists' Association.

Gale, A.S. and Schweigert, G. 2015. A new phosphatic-shelled cirripede (Crustacea, Thoracica) from the Lower Jurassic (Toarcian) of Germany - the oldest epiplanktonic barnacle. Palaeontology, doi: 10.1111/pala.12207.

Gale, A.S., Schweigert, G., Keupp, H., Röper, M., 2019, in press. Thoracican cirripede (Crustacea) from the Kimmeridgian of Brunn, Germany, and its bearing on the origin of calanticid and scalpellid barnacles. Neues Jahrbuch für Geologie und Paläontologie Abhandlungen.

Harbort, E., 1905. Die Fauna der Schaumburg-Lippe'schen Kreidemulde. Abhandlungen der Preussischen Geologischen Landesanstalt 45, 1-112, 12 pls.

Loriol, P. de, Pellat, E., 1867. Monographie paléontologique et géologique de l'étage Portlandien des environs de Boulogne-sur-Mer. Mémoires de la Société physique et d'Histoire naturelle de Genève 19, 1-200, 11 pls.

Morris, J., 1845. On the occurrence of the genus Pollicipes in the Oxford Clay. Annals and Magazine of Natural History (1)15, 30-31.

Newman, W.A., 1996. Cirripedia; suborders Thoracica and Acrothoracica. In: Forest, J. (ed.). Traité de Zoologie. Anatomie, systématique, biologie, 7(2), 453-540. Masson, Paris.

Withers, T.H., 1928. British Museum (Natural History). Catalogue of fossil Cirripedia in the Department of Geology. Vol. 1. Triassic and Jurassic, xii + 154 pp., 12 pls. Trustees of the British Museum (Natural History), London.

Woods, M.A., 2011 (compiler). Geology of south Dorset and south-east Devon and its World Heritage Coast. Special Memoir of the British Geological Survey,161 pp. NERC Publication. Keyworth, Nottingham.

Zittel, K.A. von, 1885. Bemerkungen über einige fossile Lepaditen aus dem lithographischen Schiefer und der oberen Kreide. Sitzungsberichte der Bayerischen Akademie der Wissenschaften 14 [for 1884], 577-589. 


\section{Captions}

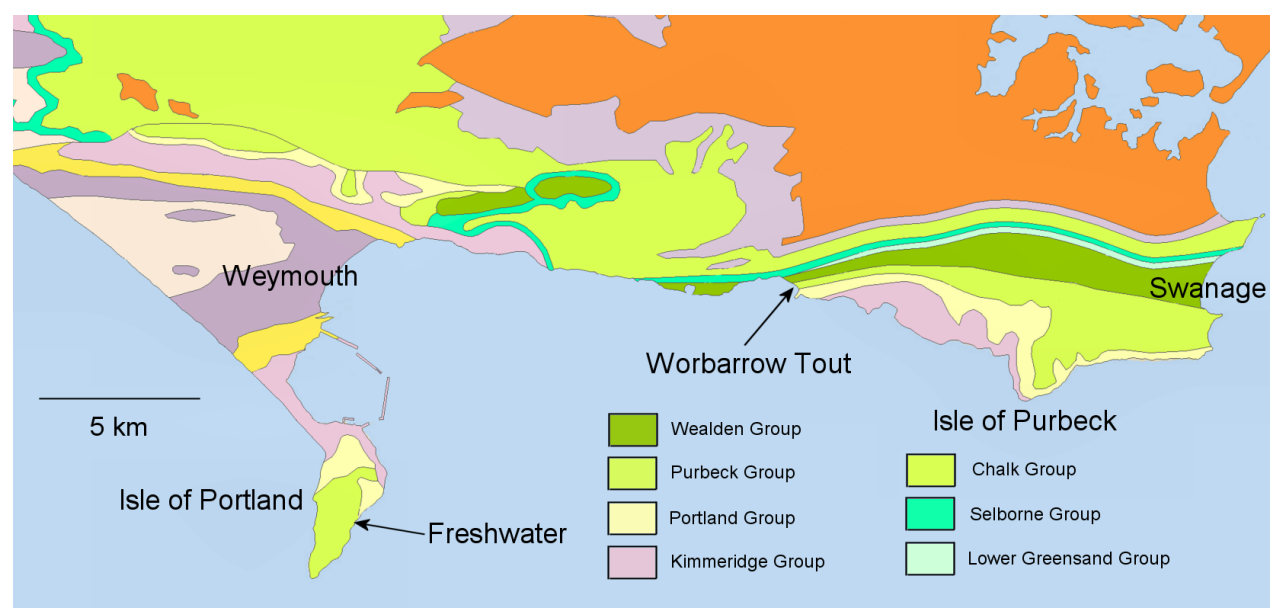

Fig. 1. Map of south-central Dorset, to show localities which have yielded the fossil cirripede material described herein. Modified after BGS digimap viewer.

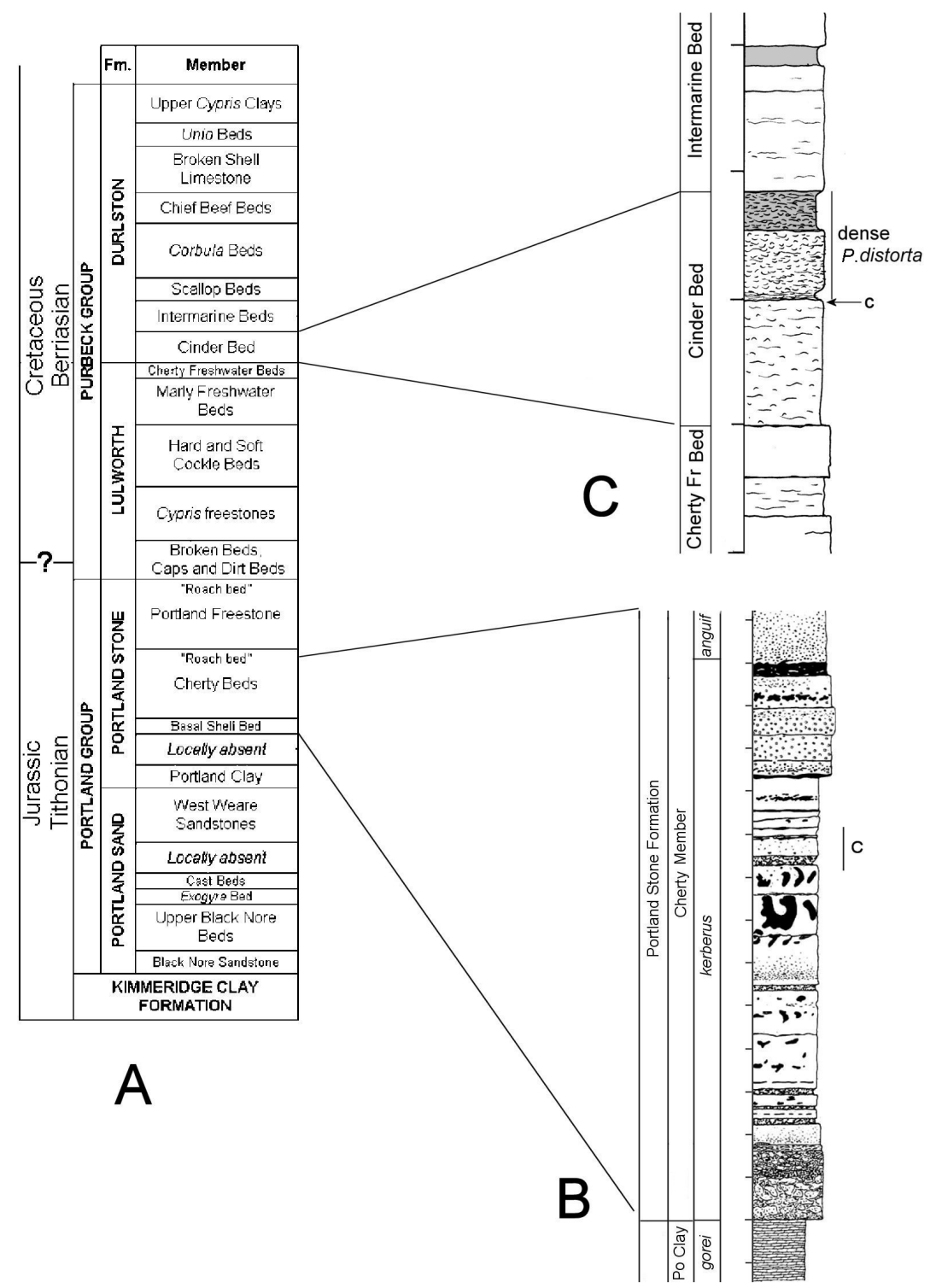


Fig. 2. A, stratigraphical column of the Portland and Purbeck groups, based on Woods (2011). B, log of the Cherty Member (Portland Stone Formation) as exposed at Freshwater, Isle of Portland, with the horizon which has yielded cirripedes marked (small letter 'c'). C, log of Cinder Bed at Worbarrow Tout, Purbeck, to show level which has yielded cirripede fossils. The Cinder Bed in Worbarrow Bay contains abundant Praexogyra distorta. Nomenclature after Ensom (1985a).
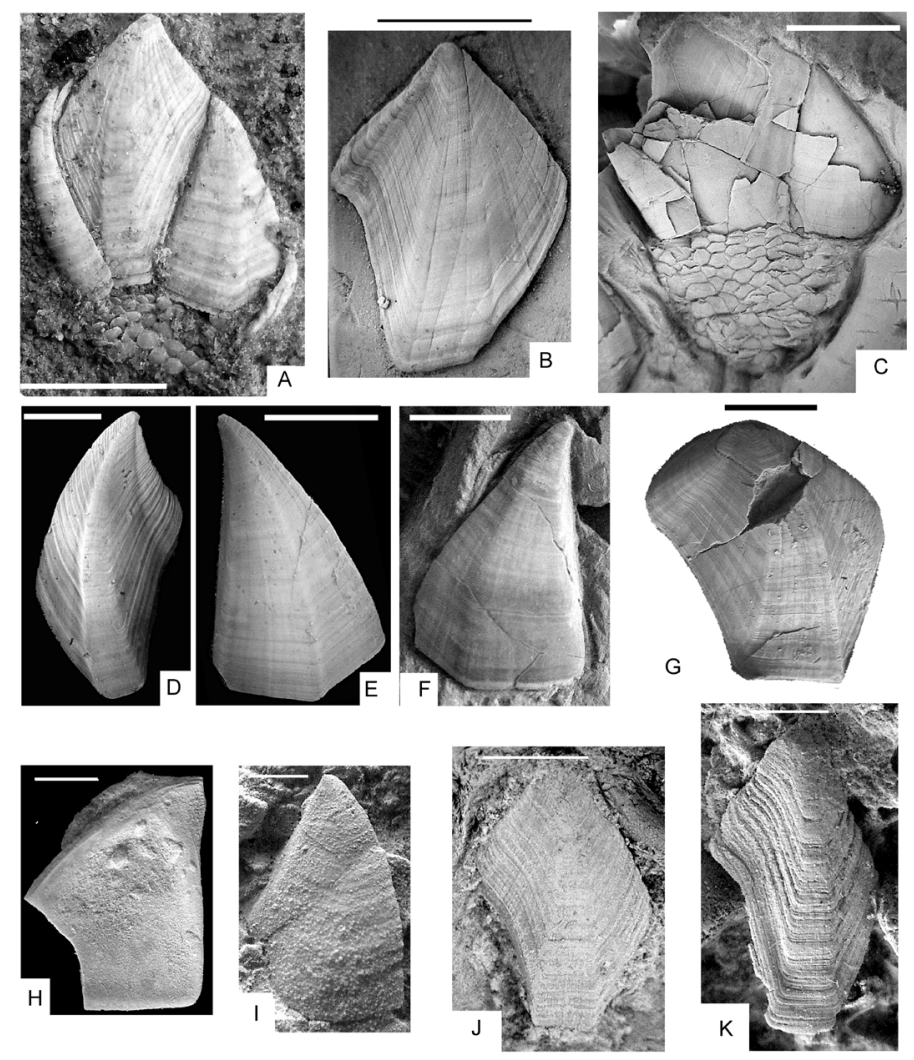

Fig. 3. A, D, E, Loriolepas suprajurensis (de Loriol, in de Loriol and Pellat, 1867); A, complete capitulum, Tithonian,Tour de Croi, near Boulogne-sur-Mer, northwest France (private collection, Paris; see fossilesboulonnais@free.fr), the original of Gale (2015, fig. 4A); D, tergum, external view (the original of Withers 1928, pl. 5, fig. 10; Gale 2015, fig. 4D), NHMUK In. 27430, Tithonian, near Boulogne-sur-Mer, France; E, scutum, external view (the original of Withers 1928, pl. 5, figs 8, 9; Gale 2015, fig. 4E), NHMUK In. 24729, Tithonian, near Boulogne-sur-Mer, France. B, Loriolepas planulata (Morris, 1845), tergum (the original of Darwin 1851, pl. 4, fig. 11; Withers 1928, pl. 5, fig. 3), NHMUK In. 24247, Oxford Clay, Callovian, Peltoceras athleta Zone, Christian Malford, Wiltshire, UK. C, F, G, Loriolepas decora (Harbort, 1905); C, lateral views of individual (the original of Gale 2015, fig. 4C); F, external view of scutum (the original of Withers 1935, pl. 1, fig. 5; Gale 2015, fig. 4F); G, external view of tergum (the original of Withers 1935, pl. 1, fig. 6; Gale 2015, fig. F), lower Valanginian, Platylenticeras heteropleurum Zone, Musingen, near Bückeberg, 
Schaumberger Lippe, northwest Germany, Geological Institute of Göttingen University. H$\mathrm{K}$, Loriolepas whytei sp. nov.; $\mathrm{H}, \mathrm{I}$, scuta, in internal $(\mathrm{H})$ and (I) external views, paratypes, NHMUK IC 1333, IC 1334. J, K, terga, external surfaces. J, paratype, Dorset County Museum, Dorchester, DCM no. G 7260. K, holotype, NHMUK IC 1332, $1 \mathrm{~m}$ above base of Cinder Bed, Warbarrow Tout, Dorset; middle Berriasian. Scale bars equal $5 \mathrm{~mm}$.

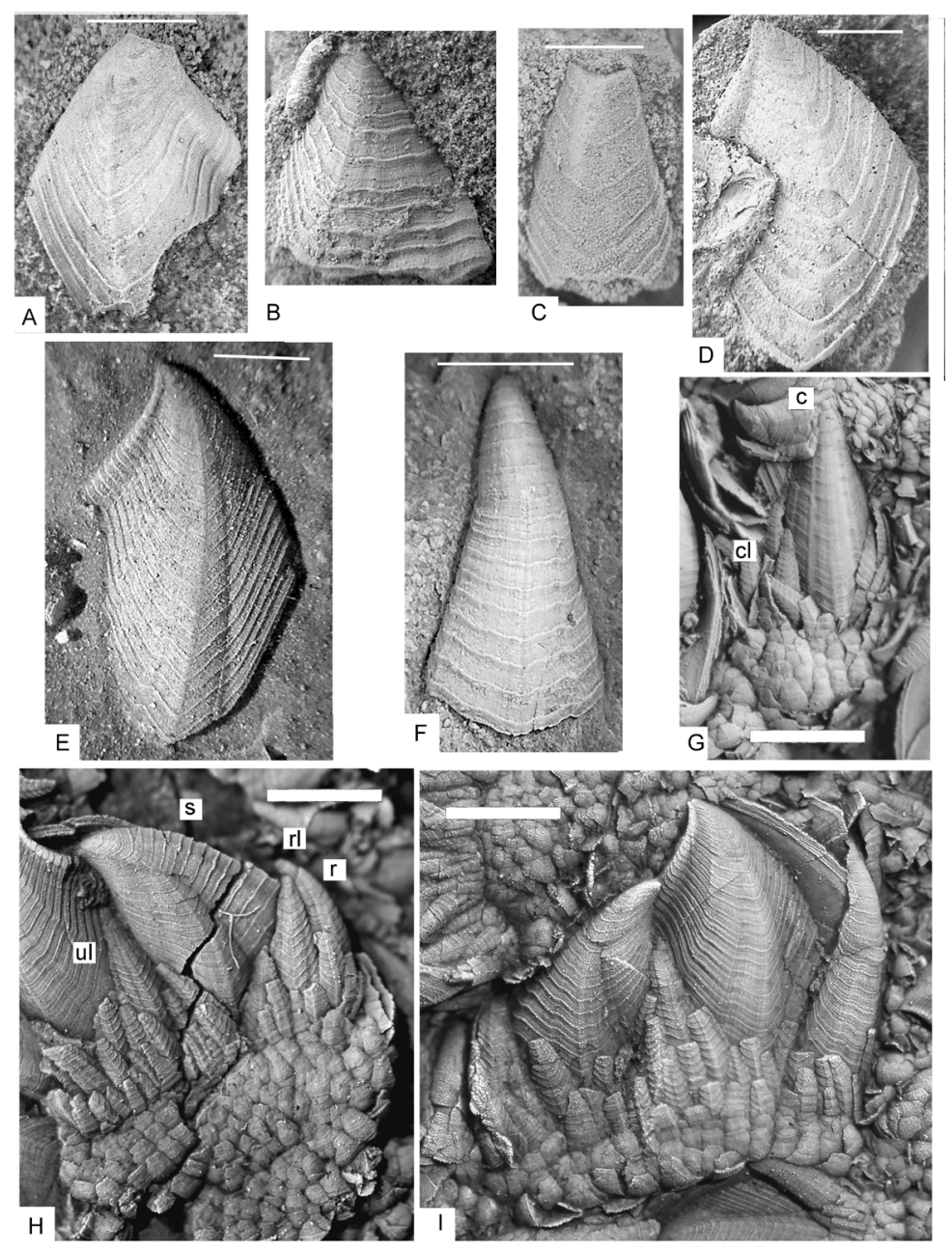

Fig. 4. A-D, Etcheslepas portlandensis sp. nov. A, D, terga; B, scutum, C, carina. A-C are paratypes (NHMUK IC 1337, IC 1338, IC 1339 ), D is the holotype (NHMUK IC 1336). Cherty Member, Freshwater, Portland, Dorset; upper Tithonian, Kerberites kusensis ammonite Zone. E-I, Etcheslepas durotrigensis Gale, 2014. E, isolated tergum (the original of Gale 2014, fig. 2D). F, carina (the original of Gale 2014, fig. 2B). G, capitulum in dorsal view (the original of Gale 2018, fig. 2B). H, I, capitula in lateral view (the originals of Gale 2018, fig. 2C, D). Level of Freshwater Steps Stone Band, Pectinatites pectinatus Zone, Tithonian, Kiimmeridge Clay, Kimmeridge, Dorset. All specimens in the MIJML collection, Kimmeridge. Scale bar equals $5 \mathrm{~mm}$. 